\title{
The African Union in Peacebuilding in Africa
}

\author{
Gilbert M. Khadiagala
}

\section{INTRODUCTION}

Since the late 1990s, peacebuilding in Africa has evolved alongside measures to strengthen continental and regional institutions for intervention in the domestic affairs of member states. Marking a decisive departure from decades where African institutions had limited roles in such interventions, these initiatives coincided with the growing optimism about the power of African institutions to help post-conflict countries to reconstruct their socioeconomic and political fabrics. In almost 20 years of engagements, the African Union (AU) has had a mixed record in peacebuilding in Africa.

On one hand, the AU has innovated by articulating and defining policies to underwrite peacebuilding initiatives, notably the African PostConflict Reconstruction and Development (PCRD) policy. Also, through the AU's Peace and Security Architecture (APSA), the AU has intervened in some post-conflict countries to help contribute to sustainable peace and development. On the other hand, the AU is a new actor in peacebuilding and thus has not had any tangible successes. For the most

\footnotetext{
G. M. Khadiagala $(\bowtie)$

University of Witwatersrand, Johannesburg, South Africa

e-mail: gilbert.khadiagala@wits.ac.za

(C) The Author(s) 2021

T. McNamee and M. Muyangwa (eds.),

The State of Peacebuilding in Africa, https://doi.org/10.1007/978-3-030-46636-7_12
} 
part, the AU has struggled with limited resources, expertise, and capacity to become an effective peacebuilding institution. In addition, the peacebuilding environment is saturated with multiple actors and interests that the AU cannot adequately compete with. In recent years, these constraints have been compounded by a resurgence of conflicts in some countries that benefitted from previous peacebuilding interventions. This has, in effect, diminished the consensus about the wisdom of peacebuilding and retarded the momentum for mobilization of resources for countries in conflicts.

This chapter weaves these themes in a narrative of Africa's attempts to build institutions of peace, security, governance, and post-conflict recovery from the early 1990s into the AU's articulation of the PCRD policy targeted at peacebuilding. I argue that while the AU has made bold moves to construct normative frameworks to strengthen common approaches to African conflicts, these efforts have yet to find critical resonance in contexts marked by the age-old fealty to sovereignty. There is a continental consensus on peacebuilding and post-conflict reconstruction that has emerged out of years of AU activism and institution-building, but it has not led to substantive shifts in state practices, limiting the effectiveness of continental and regional institutions in these domains. Equally vital, sustainable peacebuilding ultimately hinges on national governance systems led by responsible and accountable leaders who are able to initiate and galvanize policies that address the myriad drivers of conflicts, including preventing the relapse into violence. The next section briefly discusses the formative debates on peacebuilding in Africa, followed by an examination of the AU's key institutions for peace and security since its formation in 2002. In section three, the analysis will focus on the African experiences of peacebuilding before the formation of the AU as a lead-up to a discussion on the PCRD policy. Finally, I will make some recommendations relating to the future role of the $\mathrm{AU}$ in peacebuilding.

\section{Understanding Peacebuilding}

Peacebuilding is a key concept in the reconstruction of states emerging from conflicts. From this perspective, it is inseparable from post-conflict reconstruction because it captures the whole array of activities and initiatives associated with state- and nation-building in the aftermath of civil wars. ${ }^{1}$ Popularized in the early 1990s by the UN SecretaryGeneral Boutros-Boutros Ghali's Agenda for Peace, peacebuilding was 
conceptualized as the penultimate phase in a series of intervention moments including conflict prevention, peacemaking, and peacekeeping. As outlined in the report, the international community sought to:

Identify at the earliest possible stage situations that could produce conflict and to try through diplomacy to remove the sources of danger before violence results; where conflict erupts, to engage in peacemaking aimed at resolving the issues that have led to conflict; through peace-keeping, to work to preserve peace, however fragile, where fighting has been halted and to assist in implementing agreements achieved by peacemakers; to stand ready to assist in peacebuilding in its differing contexts: rebuilding the institutions and infrastructures of nations torn by civil war and strife; and building bonds of peaceful mutual benefit among nations formerly at war; and in the largest sense, to address the deepest causes of conflict: economic despair, social injustice and political oppression. ${ }^{2}$

Framed as a comprehensive repertoire of engagements in the service of peace, security, governance, and development, peacebuilding was conceived to assist countries that were widely depicted as failed states. ${ }^{3}$ In this regard, for countries recovering from conflict, peacebuilding became a linear and natural extension of peacemaking and peacekeeping, in essence, pegging the fortunes of peacebuilding on the prior intervention processes. Thus, in most post-conflict countries, the energies and resources expended in peacemaking and peacekeeping efforts, to a large extent, determined the successes of peacebuilding. In the early 1990s, for instance, hastily negotiated peace processes resulted in weak peace agreements that the parties could not implement despite the intervention of United Nations (UN) peacekeeping missions. Similarly, despite the UN's experiment in nation-building in Somalia, these efforts collapsed in part because of the failures of both peacekeeping and peacemaking.

The other critical factor in the formative debates about peacebuilding was the division of labor between international and national/local actors. The Agenda for Peace envisioned profound roles for the UN and the broader international community in steering war-torn states to recovery. Often these actors had significant roles in providing resources for peacemaking and peacekeeping where they were needed most. But despite the engagement of international actors in peacebuilding, such as the establishment in 2005 of the UN Peacebuilding Commission, there were expectations that national and local actors would gradually take more leadership in post-conflict reconstruction because these are long-term 
engagements that require national ownership, capacity, and responsibility. As the UN Secretary-General's Policy Committee stated in May 2007:

Peacebuilding involves a range of measures targeted to reduce the risk of lapsing or relapsing into conflict by strengthening national capacities at all levels of conflict management and to lay the foundation for sustainable peace and development. Peacebuilding strategies must be coherent and tailored to specific needs of the country concerned, based on national ownership, and should comprise a carefully prioritized, sequenced, and, therefore, relatively narrow set of activities aimed at achieving the above objectives. ${ }^{4}$

In recognition, therefore, of the adage that nations are built from within, and not from outside, some analysts depicted sustainable peacebuilding as limited and time-bound to permit local actors the space to strengthen local ownership. ${ }^{5}$ In practice, also, the most successful postconflict reconstruction efforts were those in which international actors gradually exited from peacebuilding initiatives. By contrast, the least successful cases have been where countries have lapsed back into conflict or where long-running peacekeeping missions such as in the Democratic Republic of the Congo (DRC) have transitioned into peacebuilding activities. $^{6}$

\section{AFricAN INITIATIVES TOWARD Peacebuilding: From the OAU to the AU}

Owing to the multiplicity of conflicts that ensued since the 1980s, Africa made momentous contributions to the articulation and elaboration of norms that have become part of contemporary international conventions and protocols. ${ }^{7}$ The civil conflicts in Chad and Uganda in the 1980s and Rwanda in the early 1990s led to novel experiments in intervention by the Organization of African Unity (OAU) and neighboring countries to make peace and restore stability. These interventions brought pressure on the OAU to rethink the long-held commitment to sovereignty and noninterference, culminating in the OAU's decision in Cairo, Egypt, in June 1993 to establish a Mechanism for Conflict Prevention, Management, and Prevention. The Cairo Mechanism enabled the Secretary-General to be proactive in conflict prevention, management, and resolution in wartorn countries. In this respect, the Secretary-General was required to 
"resort to eminent African personalities in consultation with the Authorities in their countries of origin. Where necessary, he may make use of other relevant expertise, send special envoys or special representatives as well as dispatch fact-finding missions to conflict areas." 8 Like the Cairo Mechanism, which marked a critical moment in establishing the basis for intervention in domestic affairs, the OAU's Lomé Declaration of 2000 inaugurated the principle that prohibited unconstitutional changes in government, a norm that has since formed the basis for democratization and constitutional rule in Africa.

Both norms were further solidified in the 2002 AU Constitutive Act which defines its roles in peacebuilding and post-conflict reconstruction. ${ }^{9}$ Although the AU still retains the sovereignty of member states as one of its founding principles, it reserves the right of intervention in member states under Article $4(\mathrm{~h})$ in the case of "grave circumstance, namely: war crimes, genocide and crimes against humanity." 10 Under Article 30 , the $\mathrm{AU}$ is obliged to impose sanctions on a member state where there has been an unconstitutional change of government. These articles capture the principle of non-indifference, which justifies the AU's fundamental roles in peacebuilding and post-conflict reconstruction. Overall, since its formation, the AU has attempted to become the major fulcrum for the promotion of accelerated socio-economic integration, security and stability initiatives, greater respect for human rights, and democracy in very difficult circumstances where the $A U$ is still trying to find its institutional feet and legitimacy. ${ }^{11}$

In the pursuit of common approaches to African problems, the AU created two main institutions for peacebuilding and post-conflict reconstruction which form part of the African Peace and Security Architecture (APSA): first, the Peace and Security Council (PSC), charged with the responsibility of promoting peace, security and stability, anticipating conflicts and undertaking preventative diplomacy, and making peace through the use of mediation and conciliation. The PSC has the additional responsibilities for peacebuilding, post-conflict reconstruction, humanitarian action, and disaster management. Second, APSA comprises a Continental Early Warning System for conflict prevention, the Panel of the Wise (a group of leaders who intervene to mediate conflicts), the African Standby Force (ASF) for peacekeeping purposes, and a Peace Fund, a facility to provide resources for peace support activities. ${ }^{12}$

Although the AU was established as the primary institution responsible for peace and security, the enormity of peacebuilding roles and the 
constraints it faces propelled other continental, regional, and multilateral institutions to remain relevant in peacebuilding. The New Partnership for Africa's Development (NEPAD) is a crucial program of the AU in tackling socio-economic and political factors that contribute to conflict and instability. NEPAD is also tasked with supporting post-conflict reconstruction through the mobilization of resources for the AU Peace Fund. The other African actors are the Regional Economic Communities (RECs), which the AU has engaged in peace and security issues because of proximity to post-conflict countries and their experiences in conflict management peace initiatives. At the continental level, the African Development Bank (AfDB) and the United Nations Economic Commission for Africa (UNECA) have contributed ideas and resources in peacebuilding. Similarly, bilateral and multilateral donor institutions occupy distinctive spaces in the multiple activities embodied in peacebuilding. ${ }^{13}$

Because of the involvement of many actors in peacebuilding, the AU has confronted a competitive and crowded environment that is replete with both opportunities and constraints. As it has gradually defined its peacebuilding posture, the AU is slowly starting to appreciate forging collaborations with NEPAD, AfDB, UNECA, and RECs to be effective. ${ }^{14}$ As a new institution in a field in which it has limited experience or clout, the AU is still grappling with questions about the division of labor between it and other African institutions. These dilemmas are even more heightened with respect to the AU's relationships with bilateral and multilateral donors that are oftentimes characterized by both competition and complementarity. Ultimately, decisions about when and how the AU engages with international donors in peacebuilding are dependent on the comparative strengths and resources it can bring to specific post-conflict contexts.

\section{Peacebuilding Before the African Post-Conflict Reconstruction and Development (PCRD) Policy}

Before the formation of the AU, two dominant trends characterized peacebuilding and post-conflict reconstruction in Africa. ${ }^{15}$ The first could be labeled as the "victor's peace," 16 drawing from the experiences of Uganda, Ethiopia, Eritrea, Rwanda, and Angola where strong leaders who had triumphed in the civil wars set the pace of reconstruction with the support of multilateral and bilateral donors. In Uganda, after seizing 
power in 1986, President Yoweri Museveni's National Resistance Movement (NRM) instituted a non-partisan coalition of forces that launched a remarkable process of national rejuvenation and led multiple reforms to resuscitate the economy and legitimate his authority. ${ }^{17}$

Eritrea and Ethiopia followed Uganda's reconstruction model after the end of the civil conflict in the early 1990s. In both countries, strong parties that had prosecuted the war-the Eritrean People's Liberation Front (EPLF) and the Ethiopian People's Revolutionary Democratic Front (EPRDF) - emerged as the primary players in economic and political reconstruction. ${ }^{18}$ In post-genocide Rwanda, Paul Kagame's Rwanda Patriotic Front (RPF) launched a reconstruction process that borrowed largely from the Eritrea-Ethiopia-Uganda template: rebuilding state institutions and economic, social, and infrastructural reforms. ${ }^{19}$ Like the previous cases, Rwanda's post-conflict reconstruction was dominated by a strong leader who has garnered legitimacy through the incremental improvement in social and economic conditions and the generosity of international donors who considered President Kagame as representing the new generation of African leader determined to build strong and functional states. In 2002, Angola, which had struggled for decades to find peace and stability, embarked on the process of reconstruction and reconciliation following the killing of Jonas Savimbi, leader of the National Union for the Total Independence of Angola (UNITA), by the People's Movement for the Liberation of Angola (MPLA). Subsequently, the MPLA dictated the pace of post-reconstruction unimpeded. ${ }^{20}$

The second pattern could be depicted as "democratic peacebuilding," represented by Mozambique's post-conflict reconstruction. Mozambique's experience of post-conflict reconstruction involved a relatively open and participatory trajectory after the civil war. Following the holding of the first multi-party elections in 1994, the former protagonistsFRELIMO and RENAMO — steadily learned to accommodate each other as they started on the road to economic reconstruction and social rehabilitation. Although Mozambique faced the resurgence of violence in 2013-2014 because of RENAMO's resumption of the war, the two sides have managed to return to the compromises of the mid-1990s to reinvigorate reconciliation. ${ }^{21}$ However, in recent years, a new source of Islamist insurgency in Northern Mozambique has arisen to compromise the post-conflict gains of peace and stability. ${ }^{22}$

Most of the countries transiting from war in the early to mid-2000s such as Burundi, the Central African Republic (CAR), the Democratic 
Republic of the Congo (DRC), Liberia, Sierra Leone, and South Sudan emulated the Mozambique model as they went through the various stages from peacemaking, peacekeeping, and eventually, peacebuilding that emphasized the importance of democratic institutions in the transitions. Other than the participation of RECs and the AU in peacemaking and peacekeeping initiatives in these countries, the AU had few opportunities to influence their post-conflict futures, ceding these responsibilities to the AfDB and other international donors. These latter actors could mobilize the financial and technical resources to make a difference in peacebuilding. In Sierra Leone and Liberia, the AU through the Economic Community of West African States (ECOWAS) lent broad legitimacy to the international efforts for stabilization and economic reconstruction. After the formation of the UN Peacebuilding Commission in 2005, Burundi and Sierra Leone became its first African partners, signaling the enhanced role of international actors in peacebuilding. In both countries, alongside the United Nations Development Programme (UNDP) and other donors, the UN Peacebuilding Commission implemented a number of projects meant to consolidate peace, build local capacity to manage conflicts, and prevent the recurrence of conflicts. Similarly, when the CAR appeared to be on the road to stability following the elections of 2005, the UN Peacebuilding Commission invited it as a partner in 2008 to mobilize resources for economic development and national reconciliation.

The only major initiative that the AU attempted on post-conflict reconstruction was in July 2003 when the AU Commission established a Ministerial Committee on Sudan in anticipation of the signing of the Comprehensive Peace Agreement between the North and South. Chaired by South Africa, the Committee was mandated to consult with the government of Sudan and the South Sudan People's Liberation Movement (SPLM) on post-conflict reconstruction and development needs and to mobilize African and international resources. But this committee did not make any progress in its resource mobilization campaigns.

\section{The Post-Conflict Reconstruction and Development Policy}

Soon after its formation in 2002, the AU charged NEPAD with the mandate of drafting a post-conflict policy to guide African interventions. The quandary for the drafters must have been that since the 1990s, African regional institutions had largely been marginal in peacebuilding 
initiatives as various post-conflict countries engaged international donors in economic and political reconstruction. What meaningful contribution would the AU then be expected to make in post-conflict reconstruction in circumstances where it had no prior proficiency, capacity, and resources? Moreover, since there were two previous dominant patterns of post-conflict reconstruction, what would be preferable for Africa's future? Since the policy was unveiled in 2006, these questions have remained salient in its implementation.

In an attempt to chart a different course from the linear and sequenced intervention model found in the Agenda for Peace, the PCRD sought a comprehensive approach to embrace a wide range of peacebuilding interventions and initiatives. ${ }^{23}$ In the articulation of the policy, the AU established links between peace, security, humanitarianism, and development. As stated in the preamble of the PCRD:

As the custodian of peace and security on the continent, the AU is obligated to generate a strategic framework for PCRD that is aligned to the African vision and aspirations. Furthermore, given the complexity of postconflict reconstruction initiatives, it elaborates in a comprehensive manner the entire spectrum of activity areas that are crucial for the consolidation of peace, and stipulates minimum standards of application and benchmarks for measuring performance of countries that are on their path to recovery. ${ }^{24}$ As a policy framework it provides a model that is adapted to specific country situations, and because of its reflection of African needs and aspirations, it will empower and encourage affected countries to take the lead in the reconstruction and development of their societies. ${ }^{25}$

Toward this end, the policy seeks to: (i) help address the root causes of conflict; (ii) encourage the planning and implementation of reconstruction activities; and (iii) enhance complementarities and coordination among diverse actors engaged in PCRD processes. Some of its underlying principles include African leadership, national and local ownership, and capacity-building for sustainability. Although seeking to carve out a distinctive policy, however, the PCRD's six main areas of concerns are indistinguishable from conventional approaches to peacebuilding including: (a) restoration of security; (b) managing of political transitions; (c) socioeconomic development; (d) human rights, justice, and reconciliation; and (e) women and youth. ${ }^{26}$ With respect to the critical issue of resources for post-conflict reconstruction, the PCRD suggested more African contributions to PCRD initiatives and the establishment of a joint 
AU/NEPAD Post-Conflict Reconstruction Unit to coordinate donor disbursements to PCRD programs. The Unit would also undertake advocacy and develop post-conflict reconstruction programs in partnership with RECs, civil society, and other intergovernmental organizations. ${ }^{27}$

Following the launch of the PCRD, the AU's engagement in postconflict countries did not change dramatically, reflecting the preference for peacemaking and peacekeeping engagements rather than peacebuilding. The dominant approach to post-conflict reconstruction has been the establishment of liaison offices in countries emerging from conflict. By 2016, there were 16 such offices in countries including Burundi, Côte d'Ivoire, the CAR, Guinea-Bissau, South Sudan, and Madagascar. As Chido Mutangadura has noted, "these offices have been criticized for having little impact, especially as they lack the capacity to effectively coordinate the AU's goals on the ground and link them to decisions made in Addis Ababa." 28 In South Sudan and Madagascar, the AU liaison offices did not have the resources or diplomatic clout to influence the course of events and thus amount to no more than post offices for the AU. ${ }^{29}$ In West Africa, ECOWAS has been the AU's principal entry point in resolving conflicts in Burkina Faso, The Gambia, Guinea, and Guinea-Bissau, but both ECOWAS and the AU have had no roles in the post-conflict reconstruction phase. ${ }^{30}$

Although the adoption of the PCRD policy in 2006 represented a major milestone in AU efforts to coordinate and support peacebuilding efforts, enormous organizational and operational hurdles, insufficient human and financial resources, and lack of political interest by the majority of member states have compromised effective implementation. Since its formation, the PCRD has been manned by one full-time individual working within the AU Peace and Security Department (AU PSD). In recent years, the AU has indicated the need to create an interdepartmental task force on PCRD in the AU PSD, but this office has yet to be created. To break the stalemate over the management of the PCRD, the Egyptian government agreed to establish an AU Center for PCRD in February 2019. ${ }^{31}$ It is not yet clear how the new AU Center will coordinate its roles with the AU institutions in Addis Ababa. One of the major complaints about the PCRD is that it has not sufficiently reached out to other AU organs such as the Departments of Political, Social, and Economic Affairs or RECs. Locating the new AU Center in Cairo is going to make it much more difficult to accomplish this objective. ${ }^{32}$ 
To mobilize African resources, the AU launched the African Solidarity Initiative (ASI) in July 2012 with a call to encourage African countries to assist post-conflict countries in their reconstruction and development efforts. At its launch, member countries, the AfDB, and the UNECA lauded the ASI optimistically as a unique vehicle for resource mobilization and its potential to promote peer learning and sharing best practices among post-conflict countries, but it never emerged as a credible initiative to meet the needs of the PCRD. In February 2014, South Africa's thenPresident Jacob Zuma hosted the first conference of the ASI at which African countries pledged a paltry US \$3 million for PCRD activities, reflecting the lack of political will for PCRD. ${ }^{33}$ This amount contrasts sharply with the AfDB's Fragile States Facility (now Transition Support Facility) created in 2008, with a budget of US $\$ 600$ million to provide reconstruction funds to beneficiary countries, including Liberia, Sierra Leone, the DRC, the CAR, Burundi, Côte d'Ivoire, Guinea-Bissau, and South Sudan.

Lacking any meaningful resources, the AU only managed to undertake assessment missions to the CAR (2006), Liberia and Sierra Leone (2009), the DRC and Burundi (2010), and South Sudan (2011) to ascertain the post-conflict demands of these countries. Further, to support the PCRD, the AU raised some funds to support Quick Impact Projects (QIPs) and "peace-strengthening projects" at the community level in the Comoros, Côte d'Ivoire, Liberia, Sierra Leone, and South Sudan. In 2017, the AU noted as one of its achievements, the development of operational guidelines for the adoption of the PCRD at regional and national levels, the creation of a database of African experts on PCRD, and the establishment of an AU Standing Multi-dimensional Committee on PCRD. ${ }^{34}$

The PCRD's resource limitations have reinforced its organizational, operational, and capacity deficits and contributed to the widespread African skepticism about its utility. This skepticism is captured in comments by two African analysts. According to Tim Murithi: "Even though the PCRD exists, it is, however, unclear whether the AU/NEPAD will be able to mobilize their resources and build the capacity to undertake peace-building effectively." 35 In the same vein, Richard Gueli suggested: "The inconvenient truth is that even if the AU did prepare a plan for rebuilding a country, international aid agencies would probably ignore it... In short, the AU wants ownership of reconstruction processes, yet few, if any, African governments are doing anything to challenge 
the factors that perpetuate the donor domination of the development agenda." 36

The 10th anniversary of the PCRD in October 2016 coincided with the relapse into conflicts of countries that had made steady strides in peacebuilding such as Mali, the CAR, and South Sudan raising profound questions about the lack of progress in the implementation of the PCRD policy. At the meeting, the AU Commissioner for Peace and Security, Smail Chergui, acknowledged the capacity deficits "ranging from planning and conceptualization of projects and programmes, to the execution, monitoring and evaluation at national and regional levels." ${ }^{37}$ Most participants decried the AU's failure to leverage the work of bodies such as the AfDB and the UN Peacebuilding Commission that have more experience and resources to pursue post-conflict reconstruction and called for more coherence among the various entities of the AU with the relevant expertise in PCRD. ${ }^{38}$

A more recent innovation that seeks to inject momentum in the PCRD is the deployment of an African Union Technical Support Team to The Gambia (AUTSTG) to help the country's democratic transition following the ouster of long-time authoritarian leader, Yahya Jammeh. Although not technically a post-conflict country, the AU launched the AUTSTG in 2018 to provide expertise to the government on the rule of law, democracy, transitional justice, and security sector transformation. ${ }^{39}$ Unlike the AU liaison offices which are staffed by diplomats, the ten technical experts in the AUTSTG are seconded from AU member states and work directly with government ministries to build capacity in their respective areas. While this intervention potentially marks a vital departure in efforts to implement the PCRD, there are still lingering questions about its sustainability given the uncertainties in funding and the receptiveness of the Gambian government officials to African expert entreaties.

\section{Key Recommendations}

1. National ownership of peacebuilding is essential. It is worth reiterating that peacebuilding starts and ends at national levels, with international and continental actors playing only supportive roles. The most successful experiences of peacebuilding in Africa reveal that while societies emerging out of armed conflicts face tremendous obstacles in reducing polarization, creative efforts by national 
leaders in building governance systems that are inclusive, participatory, and restore trust across communities are necessary for laying the foundations for regeneration and recovery. The primary responsibility of post-conflict reconstruction and development is, therefore, that of national governments, that must identify priorities, formulate strategies, and implement programs and activities to provide the conditions necessary for sustainable peace.

2. Manage the African Union's capacity and resource constraints in line with its comparative advantage. In the short to mediumterm, the African Union's African Post-Conflict Reconstruction and Development (PCRD) will not acquire sufficient resources to be a credible actor in post-conflict reconstruction and peacebuilding. It is unlikely that the AU will develop the expertise and capabilities in the many activities that encompass the PCRD. PCRD is a huge task for an institution that is struggling to build basic infrastructure for peace, stability, and democratic governance. Since the organizational and resource challenges that have hobbled the PCRD will not go away, it is unrealistic for the PCRD to solicit resources from donors who are devoting resources to the same post-conflict reconstruction chores. To overcome these competitive pressures for resources, the PCRD will need to disengage from areas where it lacks competence and where it cannot mobilize local resources. Without comparative competence in most of these activities, the most realistic approach would be for the AU to leave them to actors who can make a substantive contribution, particularly the African Development Bank (AfDB) and other international bodies.

3. Deepen normative frameworks for conflict prevention. The African Union should invest more efforts in consolidating the normative frameworks and shared values on democratic governance, anticorruption and economic governance, youth and women's inclusion, and transitional justice, and instill a culture of compliance through national and sub-regional instruments. The ECOWAS interventions in several countries to promote democratization and the rule of law underscore the fact that strong regional institutions are critical in the internalization of continental and regional norms. ${ }^{40}$ The regional nature of conflicts in the Sahel, the Horn of Africa, and Great Lakes regions points to the importance of 
investing in conflict prevention and early warning systems. Ultimately, conflict prevention is one of the antidotes to African conflicts.

4. Create a continental framework on peer learning for peacebuilding. There is very little learning of previous post-conflict experiences in Africa because of the absence of systematic programs for lesson drawing within the Regional Economic Communities (RECs) or the African Union. A database of comparative postconflict reconstruction experiences would be a good start in the accretion of such knowledge that will inform future interventions.

\section{Notes}

1. Jorn Grävingholt, Staffan Gänzle, and Sebastian Ziaja, Policy Brief: Concepts of Peacebuilding and State Building-How Compatible Are They? (Bonn: The German Development Institute, 2009), 3-4.

2. "An Agenda for Peace: Preventive Diplomacy, Peacemaking, and Peacekeeping," Report of the Secretary General, United Nations Doc. A/47/277-S/24111, June 17, 1992.

3. Michael Doyle and Nicholas Sambanis, Making War and Building Peace (Princeton: Princeton University Press, 2006).

4. United Nations, UN Peacebuilding Commission, 2007, 2; See also Vincent Chetail (ed.), Post-Conflict Peacebuilding: A Lexicon (London: Oxford University Press, 2009).

5. Kirsti Samuels, "Post-Conflict Peacebuilding and Constitution-Making," Chicago Journal of International Law 6, no. 2 (2016): 663-682.

6. Jennifer M. Hazen, "Can Peacekeepers be Peacebuilders?," International Peacekeeping 14, no. 2 (2007): 323-338.

7. Katharina Coleman and Thomas Tieku (eds.), African Actors in International Security: Shaping Contemporary Norms (Boulder: Lynne Rienner, 2018).

8. The Organization of African Unity, "Declarations and Resolutions Adopted by the Twenty-Ninth Ordinary Session of the Heads of State and Government," Cairo, Egypt, June 29-30, 1993.

9. Paul Williams, "The Peace and Security Council of the African Union: Evaluating an Embryonic International Institution," Journal of Modern African Studies 47, no. 2 (December 2009): 603-626.

10. The African Union, The Constitutive Act of the AU (Addis Ababa: The African Union, 2002), 1.

11. Gilbert M. Khadiagala, Regional Cooperation on Democratization and Conflict Management in Africa (Washington, DC: Carnegie Endowment for International Peace, 2018). 
12. Samuel Makinda and Wafula Okumu, The African Union: Challenges of Globalization, Security and Governance (London: Routledge, 2015); Tim Murithi, The African Union (Farnham: Ashgate, 2015).

13. Tim Murithi, "Towards a Symbiotic Partnership: The UN Peace building Commission and the Evolving AU/NEPAD Post-Conflict Reconstruction Framework," in A Dialogue of the Deaf: Essays on Africa and the United Nations, Adekeye Adebajo and Helen Scanlon (eds.) (Auckland Park, South Africa: The Centre for Conflict Resolution, 2006), 252; and Gilbert M. Khadiagala, "The Role of the African Union, New Partnership for African Development, and the African Development Bank in Postconflict Reconstruction and Peacebuilding in Africa," in Peace building, Power, and Politics in Africa, Devon Curtis and Gwinyayi A. Dzinesa (eds.) (Athens: Ohio University Press, 2012 and Wits University Press, 2012), 161-179.

14. Nieuwkerk Anthoni, "The Role of the AU and NEPAD in Africa's New Security Regime," in Peace in Africa: Towards a Collaborative Security Regime, Sharon Field (ed.) (Johannesburg: Institute for Global Dialogue, 2004), 49.

15. Tony Addison and S. Mashood Murshed, "Post-Conflict Reconstruction in Africa: Some Analytical Issues," in Post-Conflict Economies in Africa, A. K. Fosu and Paul Collier (eds.) (London: Palgrave Macmillan, 2005).

16. This notion has been popularized by Guilia Piccolino, "Local Peacebuilding in a Victor's Peace: Why Peacebuilding Fails in the Absence of National Reconciliation," International Peacekeeping 26, no. 3 (2019): 354-379.

17. Alcira Kreimer, Paul Collier, Collin S. Scott, and Margaret Arnold, Uganda: Post-Conflict Reconstruction: Country Case Studies Series (Washington, DC: World Bank Evaluation Unit, 2000).

18. M. Doornbos, L. Cliffe, A. Ahmed, and J. Markakis, Beyond Conflict in the Horn: Prospects for Peace, Recovery, and Development in Ethiopia, Somalia, and Sudan (Lawrence, NJ: Red Sea Press, 1992).

19. David Booth and F. Golooba-Mutebi, "Developmental Patrimonialism? The Case of Rwanda," African Affairs 111, no. 444 (2012): 379-403; Kladoumadje Nadjialdongar, "Lessons Learnt from Post-Conflict Reconstruction in Rwanda" (Niamey: The Sahel and West Africa Club/OECD and Economic Community of West African States, June 2008), http:// www.oecd.org/countries/rwanda/41425587.pdf.

20. Roissin Shannon, "Peacebuilding and Conflict Interventions in PostConflict Angola: NGDO's Negotiating Theory and Practice," Trocaire Development Review (2003-2004): 33-55.

21. Giovanni Faleg, Conflict Prevention in Mozambique: Can There Be Peace After the Storm? (Paris: European Institute of Security Studies, April 2019). 
22. Peter Fabricius, "Mozambique's Apparent Islamist Insurgency Poses Multiple Threats," ISS Today, November 20, 2019, https://issafrica. org/iss-today/mozambiques-apparent-islamist-insurgency-poses-multiplethreats.

23. Theo Neethling and Heidi Hudson (eds.), Post-Conflict Reconstruction and Development in Africa: Concepts, Role Players, Policy and Practice (Cape Town: University of Cape Town Press, 2013).

24. Heidi Hudson, "Looking In and or Transforming Up: Conceptual Dilemmas of Liberal Peacebuilding and PCRD," in Post-Conflict Reconstruction and Development in Africa: Concepts, Role Players, Policy and Practice, Theo Neethling and Heidi Hudson (eds.) (United Nations University Press, August 2013).

25. African Union/NEPAD, Policy Framework for Post-Conflict Reconstruction and Development, PSD/PCRD/EXP/4/1 (Addis Ababa: AU, 2006).

26. African Union/NEPAD, Policy Framework for Post-Conflict Reconstruction and Development.

27. Ibid.

28. Chido Mutangadura, "Gambia: Will the Gambia Be a Turning Point for AU's Peace Efforts?” Pretoria, Institute for Security Studies, May 19, 2019.

29. David J. Francis, "Timing and Sequencing of Post-Conflict and Peacebuilding Efforts in South Sudan," in Building Sustainable Peace: Timing and Sequencing of Post-Conflict and Peacebuilding, A. Linger and G. L. Brown (eds.) (Oxford: Oxford University Press, 2016); and Nzolani Francois Butedi, "The Work of the African Union Liaison Mission in Building Peace on the Ground in Madagascar," The South African Journal of International Affairs 25, no. 1 (2018): 99-116.

30. Kwesi Aning and Naila Salihu, "Regional Approaches to Statebuilding II: The African Union and ECOWAS," in The Political Economy of Statebuilding: Power After Peace, Mats Berdal (ed.) (London: Routledge, 2013), 74-88.

31. African Union, Establishment of an African Union Centre for Post-Conflict Reconstruction and Development (AUPCRD), Addis Ababa, Assembly of the Union, January 30-31, 2011, https://portal.africa-union.org/ DVD/Documents/DOC-AU-WD/ASSEMBLY\%20AU\%2015\%20(XVI \%20ADD\%202\%20_E.pdf.

32. Andrew Atta-Asamoah, "AU Summit 32: Egypt Takes the Wheel at the AU," ISS Today, February 7, 2019, https://www.dailymaverick.co.za/art icle/2019-02-07-au-summit-32-egypt-takes-the-wheel-at-the-au/.

33. Amanda Lucey and Sibongile Gida, "Enhancing South Africa's PostConflict Development Role in the African Union," Paper No. 256 (Pretoria: Institute for Security Studies, May 2014). 
34. African Union Peace and Security Commission, AU Post-Conflict Reconstruction and Development (PCRD), http://www.peaceau.org/ en/page/70-post-conflict-reconstruction.

35. Tim Murithi, "The AU/NEPAD Post-Conflict Reconstruction Strategy: An Analysis," Conflict Trends, October 18, 2012, 12.

36. Richard Gueli, "South Africa: A Future Research Agenda for Post-Conflict Reconstruction," African Security Review 17, no. 1 (July 2010): 89.

37. "Recent Events Show That the PSC Has to Closely Monitor and Remain Engaged in Countries Coming Out of Conflict," PSC Report (Pretoria: Institute for Security Studies, July 7, 2014), https://issafrica.org/psc report/psc-insights/spotlight-on-post-conflict-reconstruction-and-develo pment-in-africa.

38. Reliefweb, "African Union Reflects on Progress, Opportunities and Challenges for Its Post-Conflict Reconstruction and Development Policy Implementation," October 21, 2016, https://reliefweb.int/report/ world/african-union-reflects-progress-opportunities-and-challenges-itspost-conflict; and "The AU, Ten Years of AU Post-Conflict Reconstruction and Development Policy (PCRD) Implementation: A Reflection on Progress, Opportunities and Challenges" (Addis Ababa: AU, October 2016).

39. Chido Mutangadura, Gambia: Will the Gambia Be a Turning Point for AU's Peace Efforts? (Pretoria: Institute for Security Studies, May 19, 2019).

40. Gilbert M. Khadiagala, Regional Cooperation on Democratization and Conflict Management in Africa.

Open Access This chapter is licensed under the terms of the Creative Commons Attribution 4.0 International License (http://creativecommons.org/licenses/ by $/ 4.0 /)$, which permits use, sharing, adaptation, distribution and reproduction in any medium or format, as long as you give appropriate credit to the original author(s) and the source, provide a link to the Creative Commons license and indicate if changes were made.

The images or other third party material in this chapter are included in the chapter's Creative Commons license, unless indicated otherwise in a credit line to the material. If material is not included in the chapter's Creative Commons license and your intended use is not permitted by statutory regulation or exceeds the permitted use, you will need to obtain permission directly from the copyright holder.

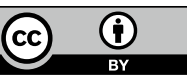

